\title{
CHARLES LAUBRY
}

It is with great regret that we learn, from a brief notice in a Swiss journal, of the death at Nantes of Professor Charles Laubry, of Paris.

The great traditions of the Paris school of cardiology have been handed down in direct line from master to pupil for over a century, starting with Corvisart and passing in turn to Bouillaud, to Potain, to Vaquez, and finally to Laubry. All these have been masters of bedside teaching and clinical observation. In our own time, the physicians trained and inspired by Vaquez, among whom Laubry was prominent, have exercised a powerful influence on cardiological teaching, especially in Latin Europe and Latin America, comparable in some ways with Mackenzie's influence in English-speaking countries. In 1908, Vaquez, assisted by Laubry and Aubertin, founded the Archives des Maladies $d u$ Cour, which for over thirty years has been a mainstay of French cardiology.

Graduating from the école Vaquez, Laubry established his own clinic, which, after several moves, eventually settled at the Hôpital Broussais in 1925 . In this ancient and dilapidated building, situated in a poor quarter of the south of Paris, and almost unaltered since the war of 1870 , Laubry organized a complete cardiological centre. Here it was my privilege to pass a month or so in 1926, when Laubry's reputation as a teacher was beginning to attract visitors from abroad.

Laubry was a man of most attractive personality. Overflowing with good nature, paternal in manner, animated in speech, he possessed in full measure all those qualities that we most admire as typically French. He was, above all, a great clinical teacher, at his best at the bedside or in the out-patient department. Here he would give impromptu a polished and complete clinical lesson without ever becoming tedious, so that one finished a ward round with the feeling that time had passed all too quickly.

Though by no means slavishly accepting all the views emanating from the Vaquez clinic at the Pitié, and rejecting, for example, the elaborate mensuration of the orthodiagram practised by Bordet, Laubry was unwavering in his loyalty and devotion to his old chief, to whom he delighted to pay public tribute. His interests covered the whole field of cardiovascular problems, and it is difficult to single out any particular aspect of his work; perhaps his contributions to the radiology of the heart deserve special mention.

Early convinced of the importance of X-ray examination through his association with Vaquez and Bordet, Laubry was fortunate in having as his assistant Robert Chaperon, a pioneer worker in this particular field; it was he 
who developed the technique of radio-opaque injection of the individual heart cavities and great vessels in situ in the cadaver, as a method of studying the anatomy of the heart; and important papers on the vascular pedicle and the composition of the lung root shadows resulted. After the untimely death of Chaperon, this work was continued and extended in co-operation with Heim de Balzac, and the fruits of many years of patient investigation were incorporated in the large treatise "Radiologie Clinique du Cour et des Gros Vaisseaux," published by Laubry and his associates in 1939 shortly before the war. This book will certainly have a permanent value in reference to all aspects of the radiological anatomy of the heart, normal and pathological.

Though his reputation rested more on the spoken than on the written word, Laubry wrote much. His book "Traité des Maladies Congénitales du Caur," written jointly with Pezzi, appeared in 1921 and is still widely quoted. His "Leçons de Sémiologie Cardiovasculaire," published in 1924, is perhaps his best-known book, and makes delightful reading, bearing comparison with the famous clinical lessons of Merklen. In 1930, he published a large text-book on heart disease, which, though excellently produced, was rather a bulky volume and never attained the popularity of Vaquez' text-book.

No account of Laubry's work would be complete without some mention of the "bruit de galop." This sign, long neglected in England, had been described in masterly fashion by Potain in 1875 , and seemed to possess a singular fascination for Laubry, who paid great attention to it in his teaching. With Pezzi, he wrote a monograph on gallop rhythm in 1926, and also made it the subject of his St. Cyres Lecture, delivered in London in 1937.

Laubry was never a professeur agrégé, and was not therefore normally eligible for a professorial chair; but when the time drew near for him to retire as a Médecin des Hôpiteaux, a special chair of Clinical Cardiology was created so that his services as a teacher could be retained. He accomplished much for French cardiology besides his purely scientific contributions. After the death of Vaquez, he took over the direction of the Archives des Maladies du Cour, and greatly improved the standard of its production, at the same time excluding from its scope diseases of the blood. In 1937 he initiated the Société Française de Cardiologie, of which he was nominated first president, Prof. Clerc and Dr. Gallavardin being joint vice-presidents. Whereas the British Heart Journal was started by the Cardiac Society, in France the reverse occurred, for the society was formed by the journal through its editorial committee. Laubry next envisaged the formation of an international society of cardiology, and broached the subject on the occasion of a dinner given in his honour in London in 1937. Unhappily events were to prove unfavourable to his project.

All who knew Laubry will wish to join with me in paying affectionate tribute to his memory, and all members of the Cardiac Society will share our regret in the passing of another of our distinguished honorary members.

D. EVAN BEDFord. 